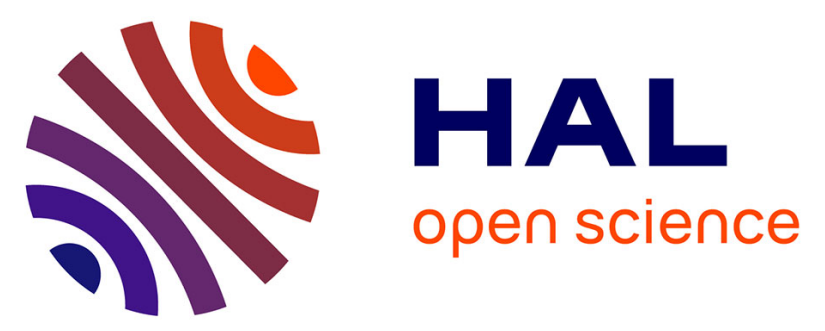

\title{
Phylogenetic relationships of a new species of seed-beetle infesting Cercis siliquastrum L. in China and in Europe (Coleoptera: Chrysomelidae: Bruchinae: Bruchini)
}

Gael Joseph Kergoat, Pierre Delobel, Axel Delobel

\section{- To cite this version:}

Gael Joseph Kergoat, Pierre Delobel, Axel Delobel. Phylogenetic relationships of a new species of seed-beetle infesting Cercis siliquastrum L. in China and in Europe (Coleoptera: Chrysomelidae: Bruchinae: Bruchini). Annales de la Société Entomologique de France, 2007, 43 (3), pp.265-271. 10.1080/00379271.2007.10697522 . hal-02657344

\section{HAL Id: hal-02657344 \\ https://hal.inrae.fr/hal-02657344}

Submitted on 29 Jul 2021

HAL is a multi-disciplinary open access archive for the deposit and dissemination of scientific research documents, whether they are published or not. The documents may come from teaching and research institutions in France or abroad, or from public or private research centers.
L'archive ouverte pluridisciplinaire HAL, est destinée au dépôt et à la diffusion de documents scientifiques de niveau recherche, publiés ou non, émanant des établissements d'enseignement et de recherche français ou étrangers, des laboratoires publics ou privés.

\section{(c)(1)}

Distributed under a Creative Commons Attribution| 4.0 International License 


\title{
Phylogenetic relationships of a new species of seed-beetle infesting Cercis siliquastrum L. in China and in Europe (Coleoptera: Chrysomelidae: Bruchinae: Bruchini)
}

\author{
Gaël Joseph Kergoat ${ }^{(1)}$, Pierre Delobel ${ }^{(2)} \&$ Alex Delobel ${ }^{(3)}$ \\ (1) INRA - Centre de Biologie et de Gestion des Populations (CBGP - UMR1062), Campus International de Baillarguet, F-34988 Montferrier-sur-Lez, France \\ (2) INRA - UMR SPO, 2 place Viala, F-34060 Montpellier, France \\ ${ }^{(3)}$ Muséum National d'Histoire Naturelle, Département Systématique et Evolution (MNHN, DSE), 45 rue Buff on, F-75005 Paris, France
}

\begin{abstract}
Bruchidius siliquastrin. sp. is described. This seed-beetle develops in pods of Cercis siliquastrum, a widely grown ornamental tree. Several recent reports reveal that this species is well established in Southern France. The presence of this species is also reported from Hungary. The relationships of this new species are investigated using both morphological data and molecular phylogenetic analyses. Our results indicate that this species is likely related to a mostly Paleotropical group, which includes members of genera Bruchidius and Conicobruchus. Hypotheses on the geographic origin of this new species are also discussed.
\end{abstract}

\begin{abstract}
Résumé. Affi nités phylogénétiques d'une nouvelle espèce de bruche ravageuse de Cercis siliquastrum $\mathrm{L}$. en Chine et en Europe (Coleoptera : Chrysomelidae : Bruchinae : Bruchini). Bruchidius siliquastrin. sp. est décrite. Cette bruche se développe dans les gousses de Cercis siliquastrum, un arbre ornemental qui est fréquemment planté à travers le monde. Des observations récentes révèlent que cette espèce est bien installée dans le sud de la France. La présence de cette espèce en Hongrie est également rapportée. Les liens de parenté de cette nouvelle espèce sont examinés à l'aide de données morphologiques et d'analyses phylogénétiques basées sur des caractères moléculaires. Nos résultats indiquent que cette espèce est vraisemblablement apparentée à un groupe majoritairement paléotropical, qui inclut des membres des genres Bruchidius et Conicobruchus. Des hypothèses concernant l'origine géographique de cette nouvelle espèce sont également discutées.
\end{abstract}

Keywords: Bruchidius siliquastrum, Conicobruchus, Judas tree, France, Hungary.

$T_{\text {sets }}^{\text {heser }}$ he genus Cercis belongs to the family Leguminosae, subfamily Caesalpinioideae, tribe Cercideae; its various species are commonly known as "redbuds". Up to ten species are currently recognized (Isely 1975; Tralau 1981; Salatino et al. 2000; Davis et al. 2002). Two of them (Ce. canadensis L. 1753 and Ce. occidentalis Torr. ex A. Gray 1850) are native to North America, while six species originate from China, one species $(C e$. griffithii Boiss. 1873) originate from Central Asia, and Ce. siliquastrum L. 1753 from Central Asia to Europe (ILDIS, 2006). Cercis siliquastrum (Mediterranean redbud, Judas tree, "arbre de Judée") is grown in all temperate regions of the world for its profusion of pink to magenta flowers. Chinese species are less commonly found in gardens, but are quite frequently planted in parks and arboretums.

Most Bruchinae recorded from Cercideae feed on seeds of various species of Baubinia; they belong to

E-mail: kergoat@supagro.inra.fr,

delobelp@supagro.inra.fr,

delobel.alex@aliceadsl.fr four different genera: Caryedon, Caryedes, Gibbobruchus and Pseudopachymerus. A single species, Gibbobruchus mimus (Say 1831), is known to predate on the two Nearctic species of Cercis (Cushman 1911; Zacher 1952; Whitehead \& Kingsolver 1975; Center \& Johnson 1976, Johnson 1977; Hetz \& Johnson 1988). The record of Callosobruchus maculatus (Fabricius 1775) on Cercis canadensis by Zacher (1952) is very doubtful and has not been confirmed. No seed-beetle has been so far recorded on any Old World species of Cercis.

In 2003, three specimens of seed-beetle emerged from a small sample of Ce. siliquastrum pods collected in Montpellier (Southern France, Hérault). These specimens proved to be new to Science and without known relative in Europe. They were found to be conspecific with specimens bred in China from an unidentified species of Cercis (K.-W. Anton, pers. comm.). Three years later, the species was collected in the Rhône valley (Valence, and as far north as Villefranchesur-Saône). This seed-beetle was also reported from Southern France in the following localities: Cadalen (Tarn) (A. Sergent, pers. comm.), Gémenos (Bouchesdu-Rhône), La Roquebrussanne (Var) (P. Ponel, pers. 
comm.) and Nice (Alpes-Maritimes) (M. Clément, pers. comm.). It was also recently reported from Hungary (O. Merkl, pers. comm.)

In this study, the new species is described and its relationships with other bruchines are investigated using both morphological data and molecular phylogenetic analyses.

\section{Material and Methods}

Samples of recently matured pods of Cercis siliquastrum were first collected in Montpellier in June 2003. Additional material was collected from the same location during the summer of 2004, from Valence (Drôme) in 2005 and from Villefranchesur-Saône (Rhône) in early 2006. Pods were kept in aerated plastic vials until emergence of adults.

\section{Morphological analysis}

Male and female genitalia were mounted on microscope slides in water-soluble DMHF (dimethyl hydantoin formaldehyde). Figures of genitalia were drawn from microphotographs of slide preparations. Male and female habitus were captured using a Canon EOS 350D digital single lens camera with a MPE $65 \mathrm{~mm}$ MACRO lens. Body length was measured from apex of pronotum to apex of elytra. The terminology of genital parts follows Kingsolver (1970).

\section{Molecular phylogenetic analyses}

DNA was extracted from an ethanol preserved specimen using the Qiagen DNeasy tissue kit (Qiagen, GmbH, Germany).

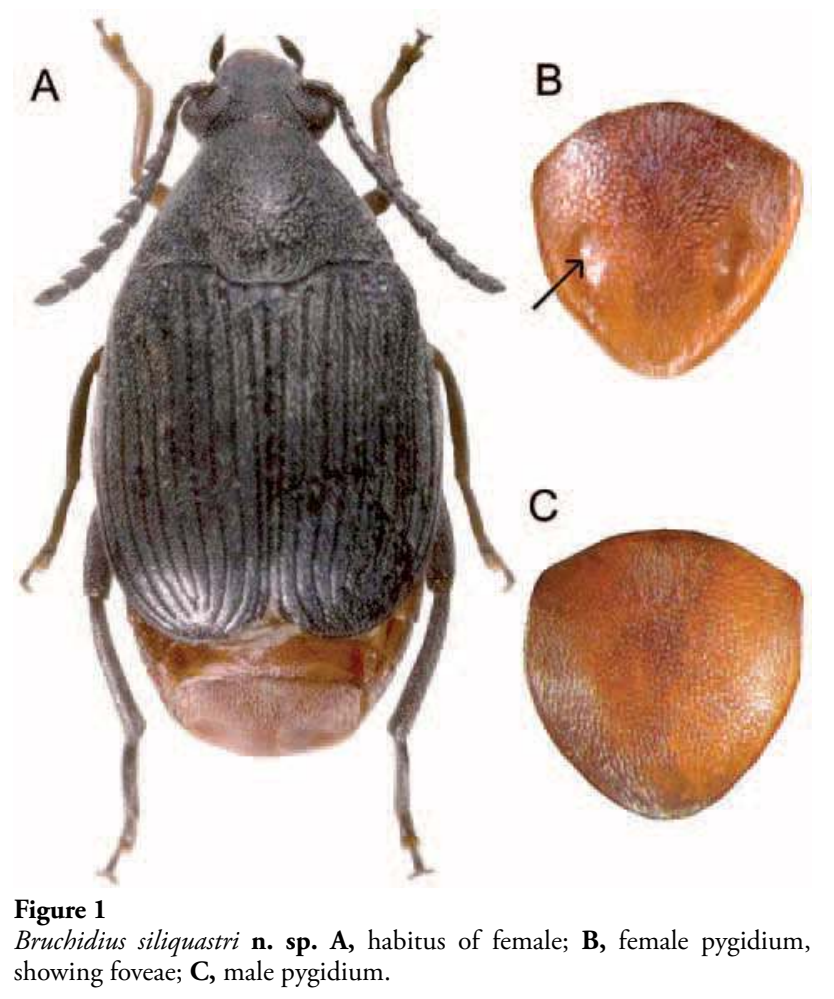

Partial sequences from three mitochondrial genes (12S rRNA, cytochrome $b$ and cytochrome $c$ oxidase subunit I) were obtained using standard protocol described elsewhere (Kergoat et al. 2004). In order to minimize the computational time of the phylogenetic analyses, a two-steps strategy was followed.

First, we have conducted preliminary analyses on a large data set of 152 species to identify the closest relatives of the new species. Genbank sequences (as well as unpublished data from G.J. Kergoat) from four genes (12S rRNA, cytochrome $b$, cytochrome $c$ oxidase subunit I and 28S-D2 rDNA) were concatenated and aligned using ClustalX (Thompson et al. 1997) with default settings. MrBayes 3.12 (Huelsenbeck \& Ronquist 2001) was used to perform partitioned Bayesian analyses (one partition per gene; two distinct runs of 10 million generations; burnin period of 100,000 generations). For each gene, the best-fit substitution model was determined using Modeltest (Posada \& Crandall 1998). In all analyses, Pachymerus cardo (Fahraeus 1839) (Chrysomelidae: Bruchinae: Pachymerini) and Gibbobruchussp. (Chrysomelidae: Bruchinae: Bruchini) were used as outgroups, following previous studies (e.g. Kergoat et al. 2005).

More thorough analyses were subsequently performed on the data set determined by preliminary analyses, using two inference methods (Bayesian inference and parsimony). Bayesian inference analyses were carried out with the settings used beforehand. For parsimony, the program PAUP* $4.0 \mathrm{~b} 10$ (Swofford 2002) was used to perform unweighted analyses with the following options: heuristic search with 1,000 random-addition replicates; Tree-bisection-reconnection (TBR) algorithm; Maxtrees set to 1,000; Random addition sequences. Since a preliminary incongruence length difference test (ILD; Farris et al. 1994) was not significant, the whole data set was analyzed simultaneously. In all parsimony analyses, gaps were considered as a fifth character following Giribet \& Wheeler (1999). The robustness of trees was assessed by non-parametric bootstrap procedures (1,000 replicates; Felsenstein 1985) for parsimony analyses and by clade posterior probabilities (CPP) for Bayesian inference analyses (Huelsenbeck et al. 2002).

\section{Results}

\section{Description of the new species}

\section{Bruchidius siliquastri Delobel, n. sp.}

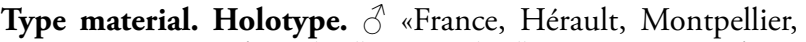
rue Las Cazes [ $\left.43^{\circ} 37^{\circ} 03^{\prime \prime N} 3^{\circ} 51^{\prime} 01^{\prime \prime} \mathrm{E}\right], 30 . V I I .2004$ ex Ce. siliquastrum, C. \& P. Delobel coll. CP97» "Bruchidius siliquastri n. sp., A. Delobel des. 1997 » " HOLOTYPE » [red]. Paratypes: 16 males, 21 females, same data and collectors as holotype; 13 males, 19 females, same data, but 24.VII.2004, ENSA Bat. 28, CP92; 1 male, 2 females, same data, but June 2003, P. Delobel coll., Fr 33; all specimens in the collections of MNHN. Additional material. 1 male, 1 female, France, Drôme,

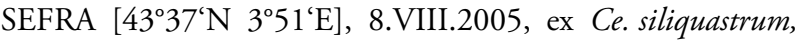
P. Delobel coll., CP051558.

Description. Length (pronotum-pygidium): 2.8-3.7 $\mathrm{mm}$.

Body (fig. 1) short ovate, integument, including legs and antennae, black, abdomen yellowish-red, except ventrite 1 partly black basally. Often extreme apex of femora and ventral 
part of hind tarsi very slightly reddish; 4 anterior (specially fore) legs sometimes not black, but rather of a dark reddish brown. Vestiture made of thin and short setae, rather dense, though not completely covering integument, recumbent, except on basal part of ventrite 1; dorsally composed of whitish setae, less dense on sides and apex of elytra, denser on disc and scutellum; on pronotum, setae longer on disc and basal lobe, becoming shorter and less dense on sides; pygidium almost uniformly covered with short and thin setae; setae moderately long on ventral side.

Male. Head short; eyes bulging, maximum head width 1.43 times width behind eyes; eyes separated by 0.35 times head width including eyes; distance between posterior rim of eyes and apex of clypeus / distance between eyes = 1.76; eye cleft to about half of its length, width at bottom of sinus composed of 7-8 ommatidia; maximum width of postocular lobes equal to $1 / 3$ "' eye width at sinus; carina on frons absent, no interocular tubercule. Antenna of moderate length, slightly surpassing elytral base; antennal segments 2-3 subcylindrical, almost equal in length, segments 5-11 widened at apex, but always longer than wide, 11 oval $(\mathrm{L} / \mathrm{W}=2.1)$. Length of antennomeres: $1.4: 1$ : 1.4 : IA: $1.5: 1.6: 1.6: 1.7: 1.7: 13: 2.6$. Pronotum strongly convex, with greatest width at base $(\mathrm{W} / \mathrm{L}=1.57$ ),subtrapezoidal, its sides convex at about $2 / 3$ of its length from base; without oblique impression on sides of basal lobe. Its disc with strong, well separated punctures, becoming stronger and slightly coriaceous laterally; punctuation suddenly interrupted on posterior half of sides, where integument is alutaceous, with a slight carina-like separation between the two areas. Elytra short, 1.04 times longer than combined width, their sides strongly convex, maximum width at middle; disc flattened; base of interstriae 2-4 margined, with a very small tooth at base of stria 3. Striae on disc well defined; interstriae flat, strongly alutaceous, with irregular lines of larger punctures. Hind femora incrassate, at their widest 1.8 times wider than mid femora; mesoventral margin carinate, with small preapical denticle, immediately followed by a much shorter one (visible

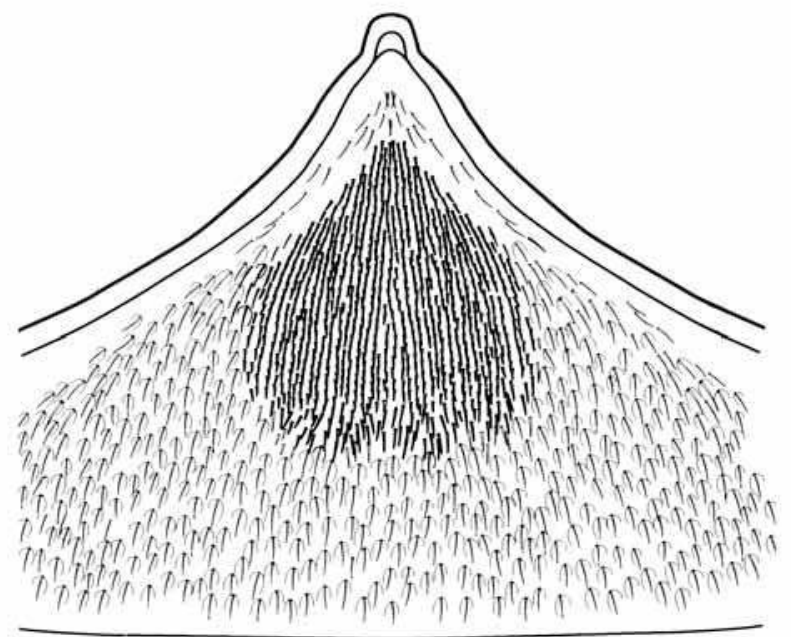

Figure 2

Bruchidius siliquastri n. sp. Detail of male ventrite 1, showing the large setiferous patch. only at higher magnification); hind tibiae widened apically, with dorsomesal and ventral carinae complete and strong, lateral not reaching base; apex of tibia with mucro shorter than width of tarsomere 1 at base; lateral denticle as long as mucro, and dorsal denticles $1 / 2$ of lateral denticle. First tarsomere ventrally without apical denticle.

Abdomen with ventrite 5 emarginate, medially as long as sternite 4; ventrite 1 basally with a large patch of short erect setae reaching beyond middle of ventrite; these setae slightly scaly, 2-3 times shorter and much denser than those on surrounding integument (fig. 2). Pygidium subcircular $(\mathrm{W} / \mathrm{L}=1.01)$, with apex turned under (see fig. 1).

Genitalia (fig. 3): Median lobe of moderate length (maximum width excluding basal hood / total length $=0.27)$; ventral valve subtriangular, moderately sclerotized, bearing numerous sensillae and on each side a row of 10 to 13 short setae; valve flanked by a pair of large hinge sclerites; internal sac with two or three large pointed denticles. Basal strut without keel. Lateral lobes cleft to 0.6 their length; apex of parameres with numerous long setae.

Female. Similar to male, but last abdomina1 ventrite not emarginate, longer than $4^{\text {th }}$ ventrite, pygidium slightly narrower than in male $(\mathrm{L} / \mathrm{W}=1.05)$, bearing a pair of elongated foveae (see fig. 1); foveae 0.3 to $0.4 \mathrm{~mm}$ long, 0.1 wide, moderately deep, unmargined, their bottom without setae, slightly alutaceous. Genitalia: spiculum gastrale as in fig. 4; spermathecal body narrow and strongly curved, with an elongated apical diverticulum; opening of spermathecal gland
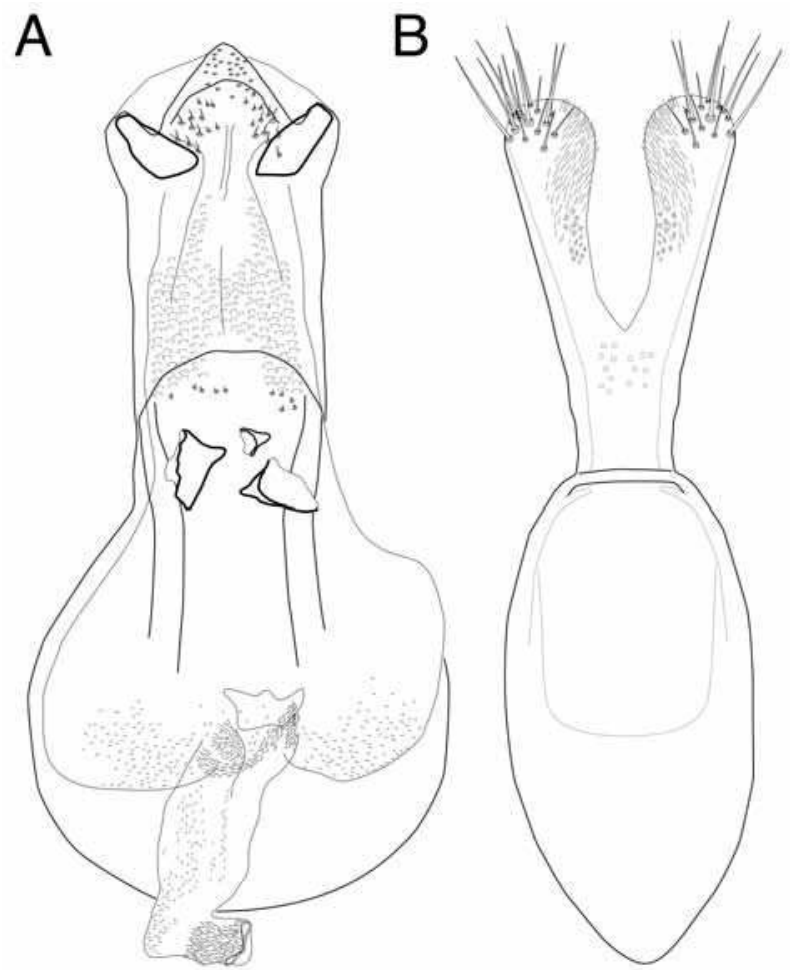

Figure 3

Bruchidius siliquastri n. sp. Male genitalia, ventral view. A, median lobe; B, tegmen. 


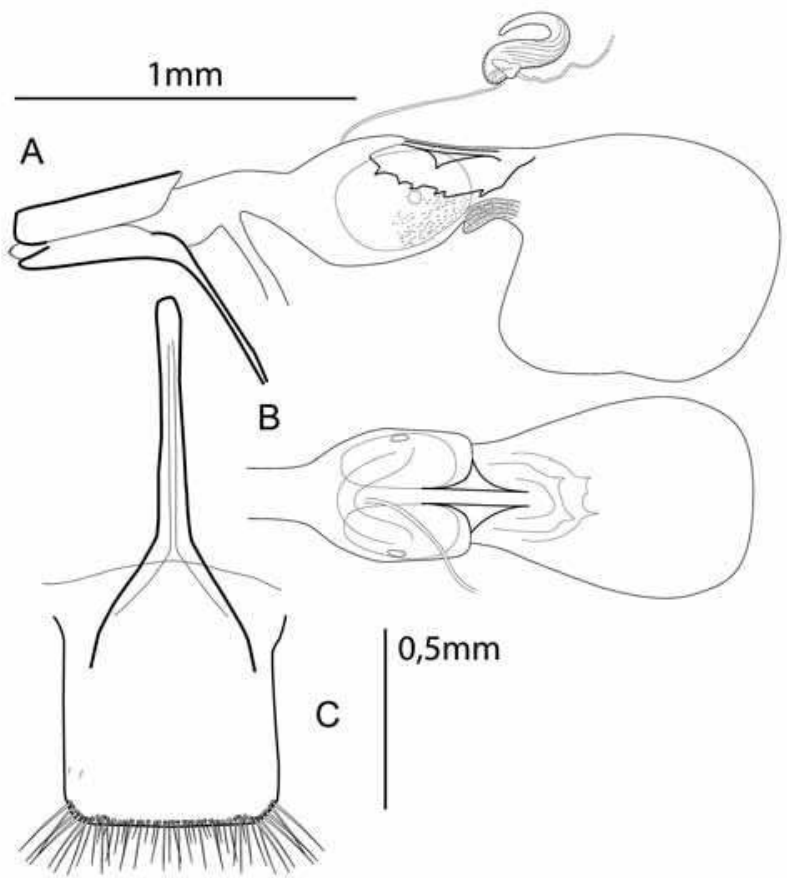

Figure 4

Bruchidius siliquastri n. sp. Female genitalia. A, lateral view; B, dorsal view; C, speculum gastrale. duct basal, contiguous with spermathecal duct opening; vagina with a large sclerite on dorsal side, a little behind spermathecal duct opening (fig. 4). Bursa copulatrix without spines or needles.

Host plants. All examined material was reared from mature seeds of Cercis siliquastrum.

Etymology. The name refers to the name of the host-plant, Cercis siliquastrum.

Distribution. China, France and Hungary. Probably present in several other European countries.

\section{Molecular phylogenetic analyses}

In all preliminary analyses, $B$. siliquastri was found clustered within a clade constituted by species belonging to genera Bruchidius Schilsky 1905, Conicobruchus Decelle 1951 and Megabruchidius Borowiec 1984. Based on this result, a subset of 21 species (including the two outgroup species) was defined (see tab. 1) and analyzed following the methods described above.

A mean sequence divergence (K2P distance) of $16.68 \pm 0.72 \%$ is found between B. siliquastri and the other 19 ingroup species (the closest species being Conicobruchus strangulatus (Fahraeus 1839), with $15.51 \%$ of divergence). This value is consistent with the mean sequence divergence of $15.53 \pm 3.70 \%$ that was found when considering the whole subset of 21 species. Bayesian inference and parsimony analyses yield topologies that are quite distinct (fig. 5). Under

Table 1. Taxon sampling.

\begin{tabular}{lcl}
\hline \multicolumn{1}{c}{ Species } & Taxonomic group (if any) & \multicolumn{1}{c}{ Locality } \\
\hline Bruchidius antennatus (Wollaston 1864) & biguttatus & Tenerife, Canary Islands \\
Bruchidius biguttatus (Olivier 1795) & biguttatus & Gard, France \\
Bruchidius chloroticus (Dalm. 1833) & & Fatick, Sénégal \\
Bruchidius cisti (Fabricius 1775) & Umbria, Italy \\
Bruchidius holosericeus (Schönherr 1832) & bolosericeus & Kfar Selouane, Lebanon \\
Bruchidius lichenicola (Wollaston 1854) & lichenicola & La Palma, Canary Islands \\
Bruchidius lineatopygus (Pic 1924) & lineatopygus & Louga, Sénégal \\
Bruchidius lutescens (Blanchard 1844) & cisti & Fokida, Greece \\
Bruchidius nodieri (Pic 1943) & & Louga, Sénégal \\
Bruchidius pauper (Boheman 1829) & pauper & Haute Corse, France \\
Bruchidius poupillieri (Allard 1868) & cisti & Basilicata, Italy \\
Bruchidius siliquastri n. sp. & & Hérault, France \\
Bruchidius unicolor (Olivier 1795) & cisti & Vaucluse, France \\
Conicobruchus albopubens (Pic 1931) & & Cabo Verde, Sénégal \\
Conicobruchus indicus (Pic 1909) & & India \\
Conicobruchus strangulatus (Fahraeus 1839) & & Cabo Verde, Sénégal \\
Gibbobruchus sp. & & Guyane française \\
Megabruchidius dorsalis (Fahraeus 1839) & & Japan \\
Megabruchidius tonkineus (Pic 1904) & Hô Chi Minh-Ville, Vietnam \\
Megabruchidius sophorae Tuda \& Morimoto 2004 & & Tsukuba, Japan \\
Pachymerus cardo (Fahraeus 1839) & & Guyane française \\
\hline
\end{tabular}


parsimony, two most-parsimonious trees (3075 steps; $\mathrm{CI}=0.459$; $\mathrm{RI}=0.357$ ) are found, which only differ by the position of B. lichenicola (Wollaston 1854). The latter species is found either as the sister species of Conicobruchus indicus (Pic 1909) or in a more basal position (see fig. 5). Interestingly, both methods recover three clades that are similar in composition (entitled A, B and C; see fig. 5). Clade A groups together the three species of Megabruchidius, with a high support (CPP and bootstrap of 100\%). Clade B is constituted by African and Asian species (with the exception of $B$. lichenicola, which is endemic to the Canary Islands) belonging to the genera Bruchidius and Conicobruchus. In this clade Bruchidius siliquastri is found either in a basal position, under Bayesian inference (CPP of 75\%), or clustered with Co. strangulatus, under parsimony (bootstrap of 29\%). Finally, clade $\mathrm{C}$ gathers the European species belonging to the Bruchidius biguttatus-cisti-holosericeus-pauper groups (sensu Borowiec 1988).

\section{Discussion}

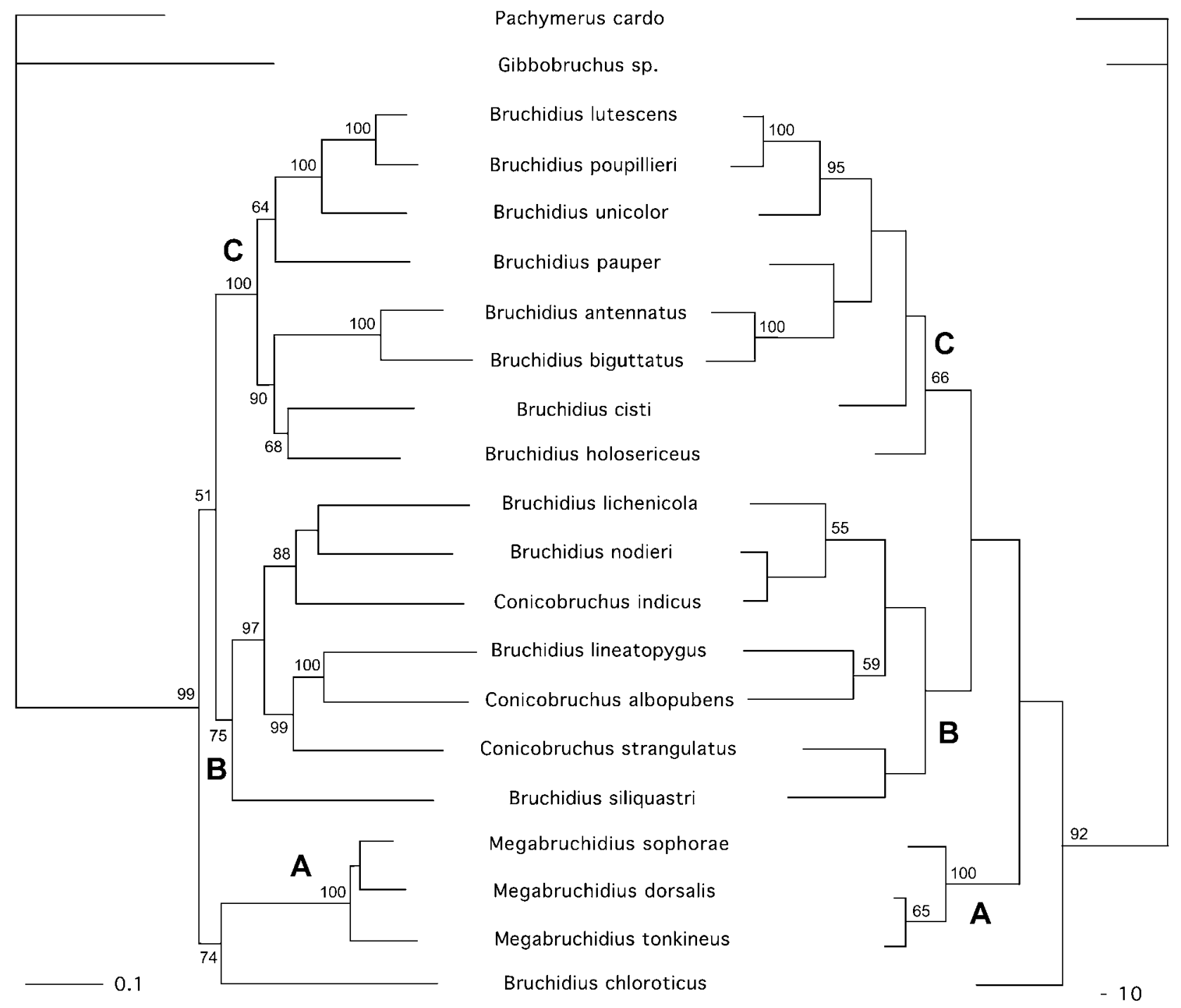

Figure 5

Phylogenetic relationships of the sampled bruchine species. The tree of the left corresponds to the result of the Bayesian inference analyses with numbers at nodes indicating CPP values (only values $>50 \%$ are figured). The tree on the right corresponds to one of the two most-parsimonious trees from the parsimony analysis of the combined data set with numbers at nodes indicating bootstrap values (only values $>50 \%$ are figured). The three clades that are recovered by both analyses are indicated by capital letters (A, B and C). 
Male morphology is characterized by the presence of a large setiferous patch on the first ventrite. Abdominal setiferous areas were described in a number of members of the subtribe Acanthoscelidina: Acanthoscelides lobatus (Fall 1910) (Johnson 1970), A. quadridentatus (Schaeffer 1907), Bruchidius aurivillii (Blanc 1889), B. uberatus (Fahraeus 1839), Megabruchidius tonkineus (Pic 1904) (Faustini \& Halstead 1982), Scutobruchus ceratiobruchus (Philippi 1859) (Kingsolver 1968), and is present in a large number of tribes, including the basal tribe Pachymerini. The presence of large hinge sclerites in the median lobe of the new species is a feature that is rather common in various African and Asian species presently known as Bruchidius or Conicobruchus spp., particularly in $B$. bimaculatopygus, $B$. confusus and $B$. lineatopygus. The particular conical sclerites of the internal sac are also of a rather uncommon type. Similar sclerites are found in Bruchidius danilevskyi Anton 1999, B. sapamoroensis Kingsolver 1984, B. savitskyi Anton 1999 and B. tuberculicauda Lukjanovitch \& Ter-Minassian 1957. But the latter four species share a ventral valve that is definitely more pointed than in the present species. Female morphology is characterized by the presence of a pair of longitudinal depressions located on the sides of the pygidium. Pygidial depressions were so far known only in the $B$. centromaculatus group (Faustini \& Halstead 1982; Anton \& Delobel 2003); foveae in $B$. siliquastri are however quite distinctive because they are not limited by any sort of carina.

Molecular analyses indicate a close relationship between $B$. siliquastri and an assemblage of species belonging to the genera Bruchidius and Conicobruchus (clade B in both trees). This grouping is also suggested by the fact that a member of this group, Co. strangulatus, exhibits the lowest level of sequence divergence with B. siliquastri. The level of support for the clade B is not high, as indicated by a moderately high CPP value $(75 \%)$ and by low bootstrap values (below 50\%). Having said that, the results of molecular analyses are consistent with the morphological evidence that brings together $B$. siliquastri with the species that possess similar large hinge sclerites in the median lobe. Interestingly the latter character is shared by all species belonging to clade $\mathrm{B}$, with the exception of $B$. lichenicola.

Though our initial sampling of 152 species was quite dense (for instance, B. aurivillii and members of $B$. centromaculatus group with pygidial depressions were included), we only partly manage to get some of the key-species that possess one of the characteristic features of $B$. siliquastri (i.e., particular sclerites of the internal sac, pygidial depressions or setiferous areas). In the absence of a denser sampling, the hypothesis of a close relationship between $B$. siliquastri and the species related to the other members of clade B thus appears as the most likely. In addition, our analyses reveal the paraphyly of the genus Conicobruchus, and the paraphyly of the group cisti. These preliminary results highlight the need of pursuing studies in the taxonomy and systematics of Old-World seed-beetles in order to clarify their phylogenetic relationships. They justify our present conservative decision not to create a new genus, and to ascribe the new species to the genus Bruchidius.

The fact that this species was also reported from unidentified species of Cercis in China, and its relatedness with non-European bruchines allows us to discuss of the likely alien status of this species in Europe. Given the rather conspicuous appearance of B. siliquastri (at least for a seed-beetle) and the wide native area of distribution of Ce. siliquastrum (from Europe and Central Asia) it seems difficult to explain why this seed-beetle was not discovered earlier. A recent shift of $B$. siliquastri from Oriental species of Cercis toward Ce. siliquastrum thus appears as the most likely explanation. We can postulate that this species is now present in many other countries (and perhaps in the New World too), due to the popularity of the European redbud as an ornamental tree. To conclude, we suggest surveying the possible development of this seed-beetle species on other commonly grown Cercis species, and especially on the two New World species that appear to be closely related with Ce. siliquastrum according to recent molecular analyses (Davis et al. 2002).

Acknowledgements. The authors wish to thank L. Soldati for his help with the preparation of the digitally captured specimens, and M. Clément, J.-P. Hébrard, P. Ponel and A. Sergent for the additional reports of this new species in France.

\section{References}

Anton K.-W., Delobel A. 2003. African species of the Bruchidius centromaculatus group with "eyed" female pygidium (Coleoptera: Bruchidae: Bruchinae). Genus 14: 159-190.

Borowiec L. 1988. Bruchidae-Strakowce (Insecta: Coleoptera). Fauna Polski, tom 11. PWN, Warszawa.

Center T.D., Johnson C.D. 1976. Host plants and parasites of some Arizona seed-feeding insects. Annals of the Entomological Society of America 69: 195-201.

Cushman R.A. 1911. Notes on the host plants and parasites of some North American Bruchidae. Journal of Economic Entomology 4: 489-510.

Davis C.C, Fritsch P.W., Li J., Donoghue M.J. 2002. Phylogeny and biogeography of Cercis (Fabaceae): Evidence from nuclear ribosomal ITS and chloroplast $n d h F$ sequence data. Systematic Botany 27: 289-302.

Farris J.S., Källersjö M., Kluge A.G., Bult. C. 1994. Testing significance of incongruence. Cladistics 10: 315-319. 
Faustini D.L., Halstead D.G.H. 1982. Setiferous structures of male Coleoptera. Journal of Morphology 173: 43-72.

Felsenstein J. 1985. Confidence limits on phylogenies: An approach using the bootstrap. Evolution 39: 783-791.

Giribet G., Wheeler W.C. 1999. On gaps. Molecular Phylogenetics and Evolution 13: 132-143.

Hetz M., Johnson C.D. 1988. Hymenopterous parasites of some bruchid beetles of North and Central America. Journal of Stored Products Research 24: 131-143.

Huelsenbeck J.P., Miller R.E., Ronquist F. 2002. Potential applications and pitfalls of Bayesian inference of phylogeny. Systematic Biology 51: 673-688.

Huelsenbeck J.P., Ronquist F. 2001. MrBayes: Bayesian inference of phylogeny. Bioinformatics 17: 754-755.

ILDIS 2005. International legume database and infornation service. Legume Web. http://www.ildis.org. Cited 15 Dec. 2005.

Isely D. 1975. Leguminosae of the United States: II. Subfamily Caesalpinioideae. Memoirs of the New York Botanical Garden 25: 1-228.

Johnson C.D. 1970. Biosystematics of the Arizona, California, and Oregon species of the seed beetle genus Acanthoscelides Schilsky (Coleoptera: Bruchidae). University of California Press, Berkeley, Los Angeles, London, $116 \mathrm{p}$.

Johnson C.D. 1977. Notes on the host plants and distribution of Acanthoscelides pauperculus (LeConte) (Coleoptera: Bruchidae). Pan-Pacific Entomologist 53: 303-304.

Kergoat G.J., Delobel A., Fédière G., Le Rü B., Silvain J.-F. 2005. Both host-plant phylogeny and chemistry have shaped the African seedbeetle radiation. Molecular Phylogenetics and Evolution 35: 602-611.
Kergoat G.J., Delobel A., Silvain J.-F. 2004. Phylogeny and hostspecificity of European seed beetles (Coleoptera, Bruchidae), new insights from molecular and ecological data. Molecular Phylogenetics and Evolution 32: 855-865.

Kingsolver J.M. 1968. A new genus of Bruchidae from South America with the description of a new species. Proceedings of the Entomological Society of Washington 70: 280-286.

Kingsolver J.M. 1970. A study of male genitalia in Bruchidae (Coleoptera). Proceedings of the Entomological Society of Washington 72: 370-386.

Posada D., Crandall K.A. 1998. MODELTEST: testing the model of DNA substitution. Bioinformatics 14: 817-818.

Salatino A., Salatino M.L.F., Giannasi D.E. 2000. Flavonoids and the taxonomy of Cercis. Biochemical Systematics and Ecology 28: 545-550.

Swofford D.L. 2002. PAUP*. Phylogenetic Analysis Using Parsimony ( ${ }^{*}$ and Other Methods). Version 4.0b10, Sinauer Associates, Sunderland, MA.

Thompson J.D., Gibson T.J., Plewniak F., Jeanmougin F., Higgins D.G. 1997. The ClustalX windows interface: flexible strategies for multiple sequence alignment aided by quality analysis tools. Nucleic Acids Researches 24: 4876-4882.

Tralau H. 1981. Index Holminiensis. Swedish Natural Science Research Council, Stockholm.

Whitehead D.R., Kingsolver J.M. 1975. Biosystematics of the North and Central American species of Gibbobruchus (Coleoptera: Bruchidae: Bruchinae). Transactions of the American Entomological Society 101:167-225.

Zacher F. 1952. Die Nährpflanzen der Samenkäfer. Zeitschrift für angewandte Entomologie 33: 460-480. 